\title{
New Delhi metallo-beta-lactamase 1-producing Enterobacteriaceae: emergence and response in Europe
}

M. J. Struelens (marc.struelens@ecdc.europa.eu) ${ }^{1}$, D L Monnet ${ }^{1}$, A P Magiorakos ${ }^{1}$, F Santos 0’Connor ${ }^{1}$, J Giesecke ${ }^{1}$, the European NDM-1 Survey Participants ${ }^{2}$

1. European Centre for Disease Prevention and Control (ECDC), Stockholm, Sweden

2. The European NDM-1 Survey Participants are listed at the end of the article

Citation style for this article:

Struelens MJ, Monnet DL, Magiorakos AP, Santos O'Connor F, Giesecke J, the European NDM-1 Survey Participants. New Delhi metallo-beta-lactamase 1-producing Enterobacteriaceae: emergence and response in Europe. Euro Surveill. 2010;15(46):pii=19716. Available online: http://www.eurosurveillance.org/ViewArticle.

aspx?Articleld=19716

Article published on 18 November 2010

Acquired carbapenemases confer extensive antibiotic resistance to Enterobacteriaceae and represent a public health threat. A novel acquired carbapenemase, New Delhi metallo-beta-lactamase 1 (NDM-1), has recently been described in the United Kingdom and Sweden, mostly in patients who had received care on the Indian subcontinent. We conducted a survey among 29 European countries (the European Union Member States, Iceland and Norway) to gather information on the spread of NDM-1-producing Enterobacteriaceae in Europe, on public health responses and on available national guidance on detection, surveillance and control. A total of 77 cases were reported from 13 countries from 2008 to 2010. Klebsiella pneumoniae was the most frequently reported species with $54 \%$. Among 55 cases with recorded travel history, 31 had previously travelled or been admitted to a hospital in India or Pakistan and five had been hospitalised in the Balkan region. Possible nosocomial acquisition accounted for 13 of 77 cases. National guidance on NDM-1 detection was available in 14 countries and on NDM-1 control in 11 countries. In conclusion, NDM-1 is spreading across Europe, where it is frequently linked to a history of healthcare abroad, but also to emerging nosocomial transmission. National guidance in response to the threat of carbapenemase-producing Enterobacteriaceae is available in approximately half of the surveyed European countries. Surveillance of carbapenemase- producing Enterobacteriaceae must be enhanced in Europe and effective control measures identified and implemented.

\section{Introduction}

New Delhi metallo-beta-lactamase 1 (NDM-1) is a newly-described metallo-beta-lactamase (MBL), first identified in 2008 in single isolates of Klebsiella pneumoniae and Escherichia coli, both recovered from a patient repatriated to Sweden after treatment in a hospital in New Delhi, India [1]. Like other acquired MBLs, NDM-1 hydrolyses all beta-lactam antibiotics except for aztreonam, which is usually inactivated by co-produced extended-spectrum or AmpC beta-lactamases. An association with other resistance mechanisms makes a majority of Enterobacteriaceae with bla $a_{\mathrm{NDM}-1}$ extensively resistant to antibiotics and susceptible only to colistin and, less consistently, tigecycline $[1,2]$.

Acquired carbapenemases are a large group of betalactamases of high structural diversity that, in most instances, hydrolyse not only carbapenems, but also oxyimino-cephalosporins and cephamycins [3]. For over a decade, different types of acquired carbapenemases have gradually begun to appear in clinical isolates of Enterobacteriaceae and other Gram-negative bacteria. In Europe, VIM-type MBLs and the socalled $K$. pneumoniae carbapenemases (KPC) are the most frequently isolated carbapenemases, although $K$. pneumoniae producing the class D OXA-48 carbapenemase is prevalent in Turkey $([3,4]$. Overall, carbapenem-resistant Enterobacteriaceae are still rare causes of human infections in most parts of Europe, except for Greece and Cyprus [3-5]. According to the 2009 data from the European Antimicrobial Resistance Surveillance Network (EARS-Net, formerly EARSS) [5] the rates of carbapenem-resistance among invasive K. pneumoniae infections were: $43.5 \%$ in Greece, $17.0 \%$ in Cyprus, $1.3 \%$ in Italy, $1.2 \%$ in Belgium and below $1 \%$ in the other 23 reporting countries [5]. Despite these generally low rates, carbapenemase-producing strains of $K$. pneumoniae harbouring either $b l a_{\mathrm{VIM}}$ or bla $a_{\mathrm{KPC}}$ have been the cause of country-wide epidemics of healthcare-associated infections in Greece, Israel, the United States (US), several Latin American countries and China, and of local outbreaks in Poland and Italy $[3,4,6]$. These epidemic strains, plasmids, and transposons bearing carbapenemases have been shown to spread when carried by patients who are transferred between hospitals [3,6]. Such introductions into healthcare systems across country borders have led to international epidemics by secondary local or regional transmission $[1-3,6]$.

After the initial report of NDM-1 from Sweden in 2008 [1], the Health Protection Agency (HPA) in the United Kingdom (UK), concerned over the rapid increase in the number of cases of human colonisation and infection 
with NDM-1 and other carbapenemase-producing Enterobacteriaceae in hospitals across the country, issued a national alert in July 2009 [7]. Similarly to the first case of NDM-1 reported by Yong et al. [1], the majority of the patients with NDM-1-positive bacteria in the UK had a history of travel to India or Pakistan, where many of them had been hospitalised with various indications, including elective surgery and renal dialysis $[2,7]$.

These reports indicate that the majority of the bacteria carry bla $a_{\mathrm{NDM}-1}$ on conjugative plasmids of variable size $[1,2]$. Among Enterobacteriaceae, E. coli and K. pneumoniae are the most frequent host species but NDM-1 has already been recorded in Klebsiella oxytoca, Citrobacter freundii, Enterobacter cloacae, Morganella morganii, Proteus spp. and Providencia spp. [1,2].

The worldwide spread of Enterobacteriaceae that carry carbapenemase-producing genes, including $b / a_{\mathrm{NDM}-1}$, is a significant threat to human health: Firstly, the production of carbapenemase, in association with other resistance determinants, confers extensive drug resistance, leaving few or no therapeutic options. Secondly, the association with travel underscores the risk of healthcare in countries where antibiotic-resistant bacteria are endemic [2]. Lastly, studies of patients infected with Enterobacteriaceae producing KPC are at increased risk of complications and death $[8,9]$.

On 23 August 2010, following publication of the UK cases [2], the French National Public Health Surveillance Institute (InVS) posted an alert on the European Early Warning and Response System (EWRS), to share with other European Union (EU) Member States information on two cases infected with NDM-1-producing bacteria related to hospitalisation on the Indian subcontinent. On 27 August, the European Centre for Disease Prevention and Control (ECDC) produced and shared with the Commission and all EU Member States a threat assessment on "New Delhi metallo-beta-lactamase (NDM-1) carbapenemase-producing Enterobacteriaceae from the Indian subcontinent", based on a preliminary review of all NDM-1-producing bacteria reported at that time in six EU member states (Belgium, France, Germany, the Netherlands, Sweden and the UK). The present study is an update of this initial assessment and describes the geographical distribution and epidemiological features of NDM-1-producing bacteria detected to date in the EU Member States, Iceland and Norway. It also reports on the availability of national guidance on detection, surveillance, notification and control of NDM-1- and other carbapenemase-producing Enterobacteriaceae in these countries.

\section{Methods}

We searched the medical literature for articles on "New Delhi metallo-beta-lactamase" OR “NDM-1" published until 15 November 2010 to identify cases reported from Europe and also included relevant references provided by consulted experts. To expand this search beyond published cases, an electronic questionnaire survey was sent out on 20 September 2010 to the ECDC National Antimicrobial Resistance Focal Points and the European Antimicrobial Resistance Surveillance Network (EARS-Net) Contact Points from all EU Member States, Iceland and Norway. The purpose of this survey was to register, by country, all cases of infection with NDM-1-producing bacteria. An NDM-1 case was defined as a patient from whom one or more Enterobacteriaceae had been isolated that expressed the NDM-1 enzyme as confirmed by an expert laboratory. The survey also collected the following clinical and microbiological data: the bacterial species producing the NDM-1 enzyme and the date of detection, the type of infection, the sex and age of the patient, the patient's clinical status at hospital discharge or at the last follow-up, any recent travel history (within the 30 days before detection of NDM1) or contact with healthcare facilities abroad (also stating in which country), and any local transmission events with known contact with a travel-associated case.

The questionnaire also included queries about whether there were published national guidelines, recommendations or guidance documents addressing the following issues in the context of carbapenemase-producing Enterobacteriaceae: methods of microbiological detection, referral of isolates to reference microbiology laboratories, notification of public health authorities, and infection control measures to limit spread.

\section{Results}

We identified 19 peer-reviewed publications on NDM-1 enzyme [1,2,10-26], of which 12 reported primary data. NDM-1 cases reported from Europe $(n=38)$ included two cases from Austria [20], two from Belgium [25], one from Denmark [23], one from France [26], two from the Netherlands $[16,24]$, one from Sweden [1] and 29 from the UK [2]. Cases were also reported from Australia [18], Canada [19], Singapore [21] and the US [10]. Infections with NDM-1-producing Acinetobacter baumannii were reported from Germany, India and the UK $[2,17,22]$. Investigations showed that the NDM-1 enzyme was frequently detected among clinical Enterobacteriaceae isolates in Chennai, Haryana, Mumbai and other Indian cities $[2,10]$.

All 29 questionnaires mailed to the countries were completed and returned. Table 1 summarises the epidemiological characteristics of the 77 patients with one or more isolates of Enterobacteriaceae with an NDM-1 enzyme (referred to as 'NDM-1 cases') reported in 13 European countries between 1 January 2008 and 7 October 2010, grouped by country of diagnosis. The total number of cases increased by year from eight in 2008, 30 in 2009 and 39 in the first nine months of 2010.

Of the 77 cases reported in the questionnaires, 51 originated from the UK. The patients' age ranged from 2 to 87 years and the male:female ratio was 0.62 . 
Species information was available for 57 isolates (from 53 patients) producing an NDM-1 enzyme. They were distributed among six species: $K$. pneumoniae $(n=31)$, E. coli $(\mathrm{n}=16)$, Enterobacter spp. $(\mathrm{n}=4), C$. freundii $(\mathrm{n}=3)$, M. morganii $(\mathrm{n}=2)$ and Proteus mirabilis $(\mathrm{n}=1)$. In addition, the UK and Germany have recorded NDM-1 enzyme in Acinetobacter spp. (Table 1).

Among the 26 cases reported in European countries other than the UK, 14 were thought to be colonised with NDM-1-enzyme-producing organisms, whereas 12 presented with infections affecting the urinary tract $(n=6)$, skin and soft tissues $(n=3)$, intra-abdominal cavity $(n=2)$, and lung $(n=1)$. Among all 77 cases reported, including from the UK, four patients developed a bloodstream infection. Seven of the 77 patients died in hospital: In a 51-year old diabetic patient, death was attributed to septic shock from a necrotic leg wound infected with an NDM-1-positive E. coli. In another case the fatal outcome was unrelated to NDM-1. For the remaining five fatal cases, information on the cause of death was not available.

Thirty-eight of the 55 cases with a travel history had a link either to the Indian subcontinent $(n=33)$ or to the Balkan region $(n=5)$. Different temporal criteria were applied to travel history by the UK and the other survey participants to define this link. Among the 29 cases in the UK, 17 had travelled to India or Pakistan in the year before detection of NDM-1. Among the 26 cases from other EU countries, 22 had travelled in the month before diagnosis to a foreign country: 13 to India, three to Pakistan, two to Kosovo, two to Serbia, one to Montenegro and one to Bosnia and Herzegovina (Table 1).

Most patients with recent travel had been hospitalised in a foreign country during the 30 days prior to the detection of NDM-1 (Table 1). In the UK, 14 of 29 patients had been admitted within the three years before detection of NDM-1 to a foreign hospital in India $(n=8)$, Pakistan $(n=4)$, India and Dubai $(n=1)$ and Spain $(n=1)$. In the other reporting countries, 18 of 26 patients been admitted in the month before detection to a foreign hospital in India $(n=10)$, the Balkans $(n=5)$ or Pakistan $(n=3)$ (Table 1$)$. It appears that the majority of these cases were admitted to foreign hospitals due to an illness or accident that occurred during the journey, although a minority were travelling for medical tourism.

Preliminary evidence suggests that 13 of 77 patients from Italy and the UK were possible secondary cases linked to other hospitalised patients who had returned from India (Table 1). In Italy, two cases with no travel history had stayed in a hospital unit to which a patient returning from India had previously been admitted. In the UK, 11 patients were involved in three clusters of possible cross-transmission. The hospital stay of two UK patients with no link to foreign countries overlapped with a travel-associated case. In another UK hospital, an endoscope-related outbreak affected nine patients six month after a travel-associated case.

National guidance was available in 14 European countries in the form of online or peer-reviewed publications, addressing the management of Enterobacteriaceae producing NDM-1 or other carbapenemases (Table 2). They all recommended clinical laboratory methods for resistance detection and required that the resistance gene is confirmed by a reference laboratory. Cyprus and Latvia reported that reference microbiological methods were under development. It is of note that NDM-1 cases were reported in 10 of 14 countries with laboratory detection guidance, compared with three of 15 countries without such guidance (Tables 1 and 2). The majority of guidance documents also outlined the procedure for notification of health authorities and recommended infection control measures in healthcare facilities. Eight countries had a full set of guidance documents. Estonia, Ireland, and Slovakia indicated that such guidance was in development.

Guidance on control measures for patients with carbapenemase-producing Enterobacteriaceae was frequently part of broader recommendations on multidrug-resistant microorganisms. Finland stated that such guidance was under development in their country. Austria and Denmark indicated that infection control guidelines were developed by public health professionals at regional or hospital level. In France, guidance on the screening of patients transferred directly from foreign healthcare facilities was under revision to be extended to all patients exposed to such care facilities in the year preceding admission to a French hospital.

\section{Discussion}

Incidence and geographical distribution

Current data indicates an increase in the spread not only of NDM-1, but also of other carbapenemase-producing Enterobacteriaceae in Europe and worldwide [2-6]. We found here 77 NDM-1 cases in 13 countries in Europe over the last three years, with the majority of cases in the UK. It is likely that the number of cases reported is underestimated, because, in most countries, infections with highly-resistant Enterobacteriaceae are not notifiable, nor do they have to be laboratory-confirmed. Moreover, microbiological guidance on the detection and identification of acquired carbapenemases in Enterobacteriaceae is available in only a minority of European countries. These countries were more likely to identify cases. Cases have also been reported in 2010 from Australia [18], Canada [19], Singapore [21], the US [10], and, according to recent media reports, from China, Israel, Japan, Kenya, Malaysia, Oman and Taiwan. The majority of cases described in our survey, as in other reports, had a history of recent travel and hospital admission on the Indian subcontinent, but there was also a smaller proportion of cases who had received hospital care in Balkan countries. Further studies should determine the risk of healthcare-associated acquisition of NDM-1 and other 
TABLE 1

Demographic characteristics and travel history of patients colonised or infected with Enterobacteriaceae producing New Delhi metallo-beta-lactamase 1 in the European Union, Iceland and Norway, 2008-2010 (N=77)

\begin{tabular}{|c|c|c|c|c|c|}
\hline Country & Number of patients & $\begin{array}{l}\text { Year of detection: } \\
\text { first case/last case }\end{array}$ & $\begin{array}{l}\text { NDM-1-producing bacterial } \\
\text { species (number of isolates) }\end{array}$ & Sex (male:female) & $\begin{array}{l}\text { Age range } \\
\text { (years) }\end{array}$ \\
\hline Austria & 3 & $2009 / 2010$ & $\begin{array}{l}\text { Escherichia coli (1), } \\
\text { Klebsiella pneumoniae (2) }\end{array}$ & $3: 0$ & $14-56$ \\
\hline Belgium & 3 & 2010 & $\begin{array}{l}\text { E. coli (2), } \\
\text { K. pneumoniae (1), } \\
\text { Morganella morganii (1) }\end{array}$ & $2: 1$ & $46-53$ \\
\hline Bulgaria & 0 & NA & NA & NA & NA \\
\hline Cyprus & 0 & NA & NA & NA & NA \\
\hline Czech Republic & 0 & NA & NA & NA & NA \\
\hline Denmark & 1 & 2010 & K. pneumoniae (1) & $0: 1$ & 57 \\
\hline Estonia & 0 & NA & NA & NA & NA \\
\hline Finland & 1 & 2010 & K. pneumoniae (1) & $1: 0$ & 46 \\
\hline France & 4 & $2009 / 2010$ & $\begin{array}{l}\text { Citrobacter freundii (1), } \\
\text { E. coli (1), } \\
\text { K. pneumoniae (1), } \\
\text { Proteus mirabilis (1) }\end{array}$ & $2: 2$ & $18-63$ \\
\hline Germany & $3^{c}$ & $2009 / 2010$ & $\begin{array}{l}\text { E. coli }(2), \\
\text { K. pneumoniae (1) }\end{array}$ & $2: 1$ & $22-70$ \\
\hline Greece & 0 & NA & NA & NA & NA \\
\hline Hungary & 0 & NA & NA & NA & NA \\
\hline Iceland & 0 & NA & NA & NA & NA \\
\hline Ireland & 0 & NA & NA & NA & NA \\
\hline Italy & 2 & 2009 & E. coli (2) & $2: 0$ & NR \\
\hline Latvia & 0 & NA & NA & NA & NA \\
\hline Lithuania & 0 & NA & NA & NA & NA \\
\hline Luxembourg & 0 & NA & NA & NA & NA \\
\hline Malta & 0 & NA & NA & NA & NA \\
\hline Nether-lands & 2 & $2008 / 2009$ & K. pneumoniae (2) & $1: 1$ & $30-66$ \\
\hline Norway & 2 & 2010 & $\begin{array}{l}\text { E. coli }(1) \text {, } \\
\text { K. pneumoniae (1) }\end{array}$ & $1: 1$ & $65-70$ \\
\hline Poland & 0 & NA & NA & NA & NA \\
\hline Portugal & 0 & NA & NA & NA & NA \\
\hline Romania & 0 & NA & NA & NA & NA \\
\hline Slovakia & 0 & NA & NA & NA & NA \\
\hline Slovenia & 2 & $2009 / 2010$ & K.pneumoniae (2) & $1: 1$ & $59-79$ \\
\hline Spain & 1 & 2010 & K.pneumoniae (1) & $1: 0$ & 36 \\
\hline Sweden & 2 & $2008 / 2010$ & $\begin{array}{l}\text { E. coli }(2) \\
\text { K. pneumoniae (1) }\end{array}$ & $2: 0$ & $59-72$ \\
\hline $\begin{array}{l}\text { United Kingdom (data } \\
\text { set 1) }\end{array}$ & $29^{c}$ & $2008 / 2009$ & $\begin{array}{l}\text { C. freundii (2), } \\
\text { Enterobacter spp.(4), } \\
\text { E. coli (5), } \\
\text { K. pneumoniae (17), } \\
\text { M. morganii (1) }\end{array}$ & $15: 13$ & $2-87$ \\
\hline $\begin{array}{l}\text { United Kingdom } \\
\text { (data set 2) }\end{array}$ & 22 & 2010 & NR & NR & NR \\
\hline
\end{tabular}

NA: not applicable; NR: data not reported

${ }^{a}$ History of travel or contact with healthcare facilities in a foreign country within 30 days prior to NDM-1 detection.

b Under United Nations Security Council Resolution 1244.

c Additional cases of Acinetobacter baumannii with an NDM-1 enzyme: Germany ( $n=1)$, United Kingdom ( $n=9)$.

${ }^{\mathrm{d}}$ Autochthonous cases staying at the same hospital unit at the same time as a patient who had previously travelled in India.

e The first case was admitted to a hospital in India with longer time interval (eight months) prior to NDM-1 detection.

f Specimen type: urine $(n=19)$, wound $(n=4)$, sputum $(n=4)$, blood $(n=3)$, other $(n=7)$.

${ }^{\mathrm{g}}$ Link to foreign country defined as having travelled within the year before NDM-1 detection in India or Pakistan or having been born there ( $\mathrm{n}=17$ ).

${ }^{\mathrm{h}}$ Healthcare link to foreign country defined as having been admitted to hospital in the previous three years ( $\mathrm{n}=14$ ): India ( $\mathrm{n=8}$ ), Pakistan ( $\mathrm{n=4}$ ), India and Dubai $(n=1)$ and Spain $(n=1)$.

'Two clusters, each comprising one index travel-associated case and one secondary case, who were both admitted to the same hospital unit during the same period.

j Cluster of nine cases associated with a contaminated endoscope, caused by the same clonal type that had been found in a travel-associated case six months earlier. 


\begin{tabular}{|c|c|c|c|c|c|c|}
\hline \multicolumn{2}{|c|}{ Clinical presentation } & \multirow[b]{2}{*}{ Fatal cases } & \multirow{2}{*}{$\begin{array}{l}\text { Recent }{ }^{\mathrm{a}} \text { travel to country } \\
\text { (number of cases) }\end{array}$} & \multirow{2}{*}{$\begin{array}{l}\text { Recent }{ }^{\mathrm{a}} \text { healthcare in } \\
\text { country } \\
\text { (number of cases) }\end{array}$} & \multirow{2}{*}{$\begin{array}{l}\text { Possible } \\
\text { secondary } \\
\text { cases }\end{array}$} & \multirow[b]{2}{*}{ Reference } \\
\hline $\begin{array}{c}\text { Cases of } \\
\text { colonisation }\end{array}$ & Cases of infection & & & & & \\
\hline 1 & $\begin{array}{l}\text { Abdominal sepsis (1), } \\
\text { Necrotising fasciitis (1) }\end{array}$ & 0 & $\begin{array}{l}\text { India (1), } \\
\text { Kosovo }^{\text {b }(1)} \\
\text { Pakistan (1) }\end{array}$ & $\begin{array}{l}\text { India (1), } \\
\text { Kosovo }^{\mathrm{b}}(1) \\
\text { Pakistan (1) }\end{array}$ & 0 & {$[20]$} \\
\hline 2 & $\begin{array}{l}\text { Sepsis from necrotic } \\
\text { wound (1) }\end{array}$ & 1 & $\begin{array}{l}\text { Kosovo }^{\text {b }} \text { and Serbia (1), } \\
\text { Montenegro (1), } \\
\text { Pakistan (1) }\end{array}$ & $\begin{array}{l}\text { Kosovo }^{\text {b }} \text { and Serbia (1), } \\
\text { Montenegro (1), } \\
\text { Pakistan (1) }\end{array}$ & 0 & {$[25]$} \\
\hline NA & NA & NA & NA & NA & NA & \\
\hline NA & NA & $\mathrm{NA}$ & NA & NA & NA & \\
\hline NA & NA & NA & NA & NA & NA & \\
\hline 1 & NA & 0 & $\begin{array}{l}\text { Bosnia and } \\
\text { Herzegovina (1) }\end{array}$ & $\begin{array}{l}\text { Bosnia and Herzegovina } \\
\text { (1) }\end{array}$ & 0 & {$[23]$} \\
\hline NA & NA & NA & NA & NA & NA & \\
\hline 1 & NA & 0 & India (1) & India (1) & 0 & \\
\hline 2 & $\begin{array}{l}\text { Skin and soft tissue } \\
\text { infection (1), Urinary tract } \\
\text { infection (1) }\end{array}$ & 0 & India (4) & India (3) & 0 & {$[26]$} \\
\hline 1 & Urinary tract infection (2) & $N R^{e}$ & $\begin{array}{l}\text { India (1), } \\
\text { Pakistan (1) }\end{array}$ & $\begin{array}{l}\text { India (1), } \\
\text { Pakistan (1) }\end{array}$ & 0 & \\
\hline NA & NA & NA & NA & NA & NA & \\
\hline NA & NA & NA & NA & NA & NA & \\
\hline NA & NA & NA & NA & NA & NA & \\
\hline NA & NA & NA & NA & NA & NA & \\
\hline 2 & 0 & 0 & 0 & 0 & $2^{d}$ & \\
\hline NA & NA & NA & NA & NA & NA & \\
\hline NA & NA & NA & NA & NA & NA & \\
\hline NA & NA & NA & NA & NA & NA & \\
\hline NA & NA & NA & NA & NA & NA & \\
\hline 2 & 0 & 0 & India (2) & 0 & 0 & {$[24]$} \\
\hline 1 & $\begin{array}{l}\text { Urinary tract infection and } \\
\text { secondary bacteraemia (1) }\end{array}$ & 0 & India (1) & India $(1)^{e}$ & 0 & \\
\hline NA & NA & NA & NA & NA & NA & \\
\hline NA & NA & NA & NA & NA & NA & \\
\hline NA & NA & NA & NA & NA & NA & \\
\hline NA & NA & NA & NA & NA & NA & \\
\hline 0 & $\begin{array}{l}\text { Pneumonia (1) } \\
\text { Urinary tract infection (1) }\end{array}$ & 0 & Serbia (1) & Serbia (1) & 0 & \\
\hline 0 & Abdominal abscess (1) & 0 & India (1) & India (1) & 0 & \\
\hline 1 & Urinary tract infection (1) & 1 & India (2) & India (2) & 0 & {$[1]$} \\
\hline NR & NRf & 5 & $N^{g}$ & $N R^{h}$ & $2^{i}$ & {$[2]$} \\
\hline NR & NR & NR & NR & NR & $9^{l j}$ & \\
\hline
\end{tabular}




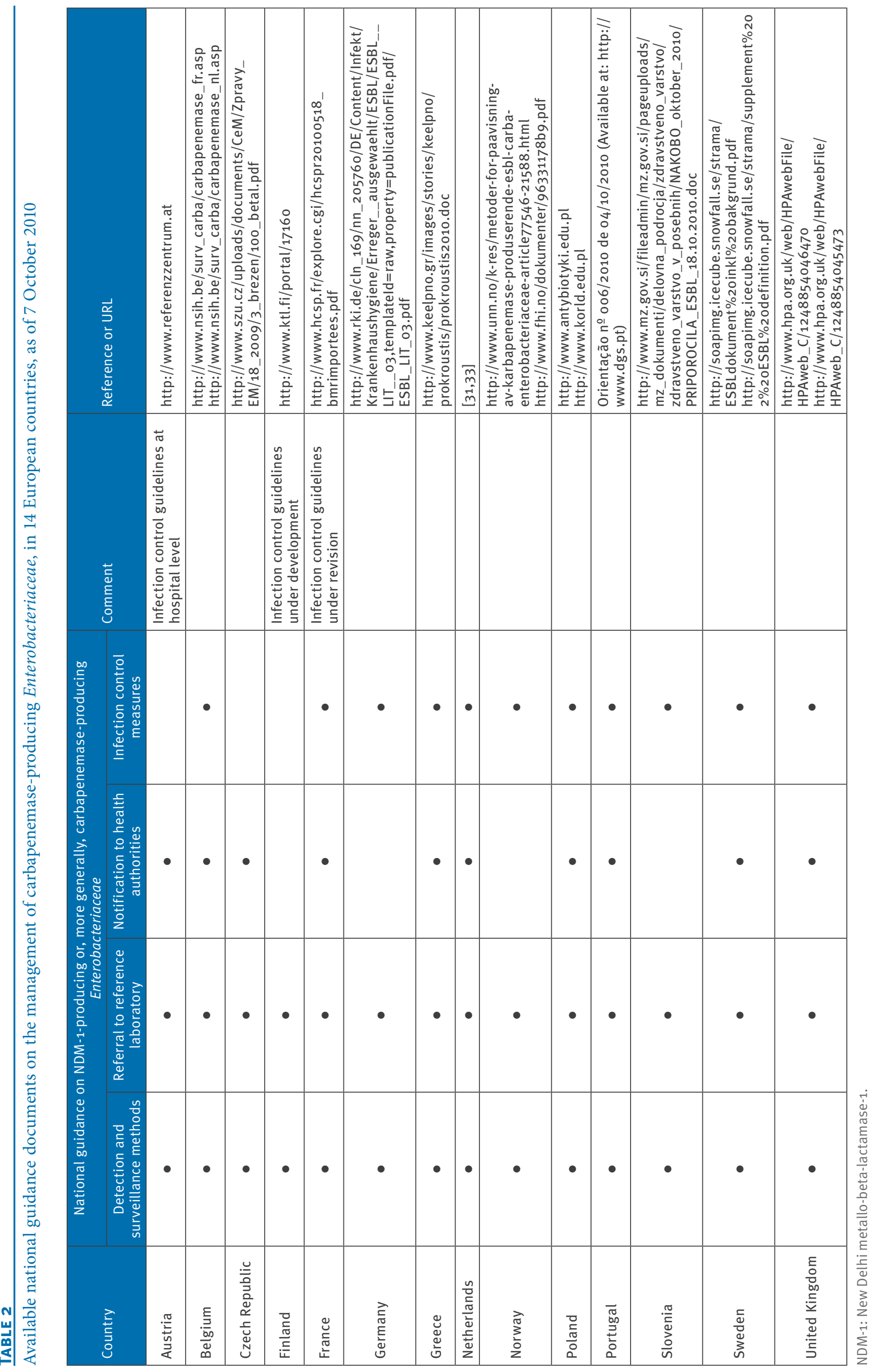


carbapenemase-producing Enterobacteriaceae in different parts of the world.

\section{Laboratory detection and identification}

Carbapenem resistance mediated by NDM-1 enzyme has been detected by clinical laboratories with routine phenotypic testing methods, including disc diffusion testing $[1,2,10,11,18-26]$. Any Enterobacteriaceae isolate that exhibits a minimum inhibitory concentration (MIC) above the epidemiological cut-off or with clinical resistance to ertapenem, imipenem or meropenem should trigger further testing $[12,27]$ Carbapenemase activity can be screened by using the modified Hodge test [2,10-12] and, as with other metallo-beta-lactamases, synergy can be detected by EDTA-imipenem disc or Etest $[1,2,10-12$,$] . Widely used automated suscepti-$ bility systems show good sensitivity but poor specificity for detection of carbapenem resistance mediated by NDM-1 and other carbapenemases [13]. Further evaluation of in-house and commercial test systems with larger numbers of NDM-1-producing strains are desirable, given the variable phenotypic expression of carbapenemase activity, as observed with strains producing KPC- and VIM-like enzymes [3,6,11,14,15,27]. Confirmation of the NDM-1 enzyme requires molecular analysis, typically PCR or DNA sequencing, by a reference laboratory $[1,2,7,11]$. A limitation of our study was the absence of a molecular case definition or a description of molecular NDM-1 identification methods. However, 38 of 77 cases described here have been published elsewhere with details of molecular identification (Table 1) and the majority of the remainder were reported by the same expert laboratories according to published national standards (Table 2 ).

\section{Epidemic risk assessment}

What is the epidemic potential of NDM-1? The bla $a_{\mathrm{NDM}-1}$ determinant was located on conjugative plasmids in the majority of the producer $E$. coli and $K$. pneumoniae clinical isolates [2]. In a few isolates, bla $a_{\mathrm{NDM}-1}$ was located on the bacterial chromosome, indicating intragenomic recombination [2]. NDM-1 was produced both by a $K$. pneumoniae isolate from urine and a faecal $E$. coli isolate from the same patient, suggesting in vivo transfer [1]. These characteristics indicate a potent capacity for horizontal dissemination, as further evidenced by detection of bla $a_{\mathrm{NDM}-1}$ in multiple genera of Enterobacteriaceae and in A. baumannii $[2,11]$.

Many NDM-1 cases had co-morbidities and/or had undergone an invasive care procedure [1,2,19-26]. The clinical spectrum and severity of illness appears similar to that expected for Enterobacteriaceae infections in this patient population. There is a paucity of information on the extent and mode of transmission of NDM-1producing bacteria in the community and in healthcare settings. By analogy with the epidemiology of the bacterial host, indirect faecal-oral inter-human transmission is likely to play a major role, via contaminated hands, food or water, particularly in countries with limited access to adequate sanitary infrastructure. In India, the majority of NDM-1-producing Enterobacteriaceae were community-acquired [2,7]. In the present survey, travel-associated cases who had had no contact with healthcare systems presumably acquired NDM-1 in the community $[16,24]$.

\section{Control interventions}

Screening of colonisation with multidrug-resistant organisms upon admission to hospitals has been advocated in patients who have received healthcare in endemic countries or epidemic facilities [28-31]. Further interventions include preemptive isolation of these patients in single bedrooms and barrier precautions for the period while the screening results are pending, and continued for colonised patients [28-31]. So far, evidence of secondary nosocomial transmission of bacteria with the NDM-1 enzyme in Europe is limited, possibly as the result of such proactive infection control measures. Evidence-based control measures should be identified for all carbapenemase-positive bacteria and implemented in patient care.

\section{Public health response}

Public health preparedness for the control of carbapenemase-producing Enterobacteriaceae, including those producing NDM-1 enzyme, is progressing across Europe as evidenced by our survey (Table 2). Key components of current public health practices include (i) dissemination of national guidelines for microbiological laboratory detection, and (ii) recommendations for active surveillance and additional infection control precautions for patients who have received cross-border healthcare. Laboratory and epidemiological support should be readily available for the investigation of imported or indigenous cases and for the control of secondary transmission. Recent experiences with large epidemics of KPC and VIM carbapenemase-producing Enterobacteriaceae associated with significant mortality in the US, Greece and Israel, have highlighted the need for strengthening public health and the response capacity of healthcare systems, notably by dedicated national task forces and public health laboratory networks [28-30]. Member States could also consider providing information to their citizens seeking healthcare in foreign countries about the risk of acquiring NDM-1 and other extensively antibiotic-resistant bacterial pathogens.

EU-wide surveillance should be strengthened to enable monitoring of extensively antibiotic-resistant pathogens such as carbapenemase-producing Enterobacteriaceae. Linking national reference laboratories and public health institutes through antimicrobial resistance surveillance networks such as the EARS-Net, implementing national generic communicable diseases reporting and early warning systems to ensure rapid communication and a timely response, could be further studied as best practice to be shared among countries for effective containment of these extensively resistant pathogens. At the EU level, rapid information exchange by means of electronic communication platforms such 
as the Epidemic Intelligence System (EPIS) [32] or the Early Warning and Response System (EWRS) would result in an integrated European approach.

\section{European NDM-1 Survey Participants:}

Austria - A. Grisold, G. Zarfel; Belgium - B. Jans; Bulgaria - T. Velinov, T. Kantardjiev; Cyprus - M. Alexandrou; Czech Republic - H. Zemlickova, J. Hrabak; Denmark - N. Frimodt-Møller, A.M. Hammerum; Estonia - M. Maimets, M. Ivanova; Finland - J. Jalava, M. Rummukainen; France - RAISIN (French Healthcare-Associated Infection Alert, Investigation and Surveillance Network); Germany - T. Eckmanns, M. Kaase; Greece - X. Dedoukou, A. Vatopoulos; Hungary - K. Böröcz; Iceland - K.G. Kristinsson, O. Gudlaugsson; Ireland - R. Cunney; Italy - G.M. Rossolini, A. Pantosti; Latvia U. Dumpis, A. Balode; Lithuania - R. Valinteliene; Luxembourg - P. Weicherding; Malta - M. Borg; Netherlands -M.A. Leversteinvan Hall, X. Huijsdens; Norway - Ø. Samuelsen, G.S. Simonsen; Poland - W. Hryniewicz, M. Gniadkowski; Portugal - A.C. Costa, M. Caniça; Romania - I. Codita, R. Serban; Slovakia - L. Siegfried, M. Stefkovicova; Slovenia - J. Kolman, M. Pirš; Spain - J. Oteo, J. Campos; Sweden - K. Tegmark-Wisell, P. Edquist; United Kingdom D. Livermore, N. Woodford

\section{References}

1. Yong D, Toleman MA, Giske CG, Cho HS, Sundman K, Lee K, et al. Characterization of a new metallo- $\beta$-lactamase gene, blaNDM-1, and a novel erythromycin esterase gene carried on a unique genetic structure in Klebsiella pneumoniae sequence type 14 from India. Antimicrob Agents Chemother. 2009;53(12):5046-54.

2. Kumarasamy KK, Toleman MA, Walsh TR, Bagaria J, Butt F, Balakrishnan R, et al. Emergence of a new antibiotic resistance mechanism in India, Pakistan, and the UK: a molecular, biological, and epidemiological study. Lancet Infect Dis. 2010;10(9):597-602.

3. Nordmann P, Cuzon G, Naas T. The real threat of Klebsiella pneumoniae carbapenemase-producing bacteria. Lancet Infect Dis. 2009;9(4):228-36.

4. Vatopoulos A. High rates of metallo-beta-lactamaseproducing Klebsiella pneumoniae in Greece - a review of the current evidence. Euro Surveill. 2008;13(4): pii=8023. Available from: http://www.eurosurveillance.org/ViewArticle. aspx?Articleld $=8023$

5. European Antimicrobial Resistance Surveillance Network (EARS-Net) database. [Internet]. Stockholm: European Centre for Disease Prevention and Control. Available from: http:// ecdc.europa.eu/en/activities/surveillance/EARS-Net/Pages/ Database.aspx

6. Queenan AM, Bush K. Carbapenemases: the versatile betalactamases. Clin Microbiol Rev 2007;20(3):440-458

7. Health Protection Agency. Multi-resistant hospital bacteria linked to India and Pakistan. Health Protection Report. 2009;3(26):3-4. [Accessed 20 August 2010]. Available from: http://www.hpa.org.uk/hpr/archives/2009/hpr2609.pdf

8. Patel G, Huprikar S, Factor SH, Jenkins SG, Calfee DP. Outcomes of carbapenem-resistant Klebsiella pneumoniae infection and the impact of antimicrobial and adjunctive therapies. Infect Control Hosp Epidemiol. 2008;29(12):1099-106.

9. Borer A, Saidel-Odes L, Riesenberg K, Eskira S, Peled N, Nativ $\mathrm{R}$, et al. Attributable mortality rate for carbapenem-resistant Klebsiella pneumoniae bacteremia. Infect Control Hosp Epidemiol. 2009;30(10):972-6.

10. Centers for Disease Control and Prevention (CDC). Detection of Enterobacteriaceae isolates carrying metallo-betalactamase - United States, 2010. MMWR Morb Mortal Wkly Rep. 2010;59(24):750. Available from: http://www.cdc.gov/mmwr/ preview/mmwrhtml/mm5924a5.htm

11. Deshpande P, Rodrigues C, Shetty A, Kapadia F, Hedge $A$, Soman R. New Delhi metallo- $\beta$ lactamase (NDM-1) in Enterobacteriaceae: treatment options with carbapenems compromised. J Acad Physicians India. 2010;58:147-9.

12. Krishna B. New Delhi metallo-beta-lactamases: A wake-up call for microbiologists. Indian J Med Microbiol. 2010;28(3):265-6.

13. Muir A, Weinbren MJ. New Delhi metallo-beta-lactamase: a cautionary tale. J Hosp Infect. 2010;75(3):239-40.

14. Abdul Gharfur K. An obituary-on the death of antibiotics! J Acad Physicians India. 2010;58:143-4.
15. Woodford N, Eastaway AT, Ford M, Leanord A, Keane C, Quayle RM, et al. Comparison of BD Phoenix, Vitek 2, and MicroScan automated systems for detection and inference of mechanisms responsible for carbapenem resistance in Enterobacteriaceae. J Clin Microbiol. 2010;48(8):2999-3002.

16. Leverstein-van Hall MA, Stuart JC, Voets GM, Versteeg D, Roelofsen E, Fluit AC. Carbapenem-resistant Klebsiella pneumoniae following foreign travel.Ned Tijdschr Geneeskd. 2010;154(37):A2013. Dutch.

17. Karthikeyan K, Thirunarayan MA, Krisnan P. Coexistence of blaOXA-23 with blaNDM-1 and armA in clinical isolates of Acinetobacter baumannii from India. J Antimicrob Agents Chemother. 2010;65(10):2253-70.

18. Poirel L, Lagrutta E, Taylor P, Pham J, Nordmann P. Emergence of metallo- $\beta$-lactamase NDM-1-producing multidrug resistant Escherichia coli in Australia. Antimicrob Agents Chemother. 2010;54(11):4914-6.

19. Mulvey MR, Grant JM, Plewes K, Roscoe D, Boyd DA. New Delhi metallo- $\beta$-lactamase in Klebsiella pnemoniae and Escherichia coli, Canada. Emerg Infect Dis. 2011 Jan. [Epub ahead of print]

20. Zarfel G, Hoenigl M, Leitner E, Salzer HJF, Feierl G, Masoud L, et al. Emergence of New Delhi metallo- $\beta$-lactamase, Austria. Emerg Infect Dis. 2011 Jan. [Epub ahead of print].

21. Koh TH, Khoo CT, Wijaya L, Leong HN, Lo YL, Lim LC, et al. Global spread of New Delhi metallo- $\beta$-lactamase 1 . Lancet Infect Dis. Forthcoming 2010 Dec.

22. Göttig S, Pfeifer Y, Wichelhaus TA, Zacharowski K, Bingold $\mathrm{T}$, Averhoff $\mathrm{B}$, et al. Global spread of New Delhi metallo- $\beta$ -lactamase 1. Lancet Infect Dis. Forthcoming 2010 Dec.

23. Hammerum AM, Toleman MA, Hansen F, Kristensen B, Lester $\mathrm{CH}$, Walsh TR, et al. Global spread of New Delhi metallo- $\beta$ lactamase 1. Lancet Infect Dis. Forthcoming $2010 \mathrm{Dec}$.

24. Leverstein-Van Hall MA, Cohen Stuart J, Voets GM, Versteeg D, Tersmette T, Fluit AC. Global spread of New Delhi metallo- $\beta$ lactamase 1. Lancet Infect Dis. Forthcoming 2010 Dec.

25. Bogaerts P, Verroken A, Jans B, Denis O, Glupczynski Y. Global spread of New Delhi metallo- $\beta$-lactamase 1 . Lancet Infect Dis. Forthcoming 2010 Dec.

26. Poirel L, Hombrouck-Alet S, Freneaux C, Bernabeu S, Nordmann P. Global spread of New Delhi metallo- $\beta$-lactamase 1 . Lancet Infect Dis. Forthcoming $2010 \mathrm{Dec}$.

27. Vading M, Samuelsen $\varnothing$, Haldorsen B, Sundsfjord AS, Giske CG. Comparison of disk diffusion, Etest and VITEK 2 for detection of carbapenemase-producing Klebsiella pneumoniae with EUCAST and CLSI breakpoint systems. Clin Microbiol Infect. 2010 Jul 23. [Epub ahead of print].

28. Carmeli Y, Akova M, Cornaglia G, Daikos GL, Garau J, Harbarth S. et al. Controlling the spread of carbapenemase-producing Gram-negatives: therapeutic approach and infection control. Clin Microbiol Infect. 2010;16(2):102-11.

29. Centers for Disease Control and Prevention (CDC). Guidance for control of infections with carbapenem-resistant or carbapenemase-producing Enterobacteriaceae in acute care facilities. MMWR Morb Mortal Wkly Rep. 2009;58(10):2566o. Available from: http://www.cdc.gov/mmwr/preview/ mmwrhtml/mm5810a4.htm

30. Bilavsky E, Schwaber MJ, Carmeli Y. How to stem the tide of carbapenemase-producing enterobacteriaceae?: proactive versus reactive strategies. Curr Opin Infect Dis. 2010;23(4):327-3.

31. Kluytmans-Vandenbergh MF, Kluytmans JA, Voss A. Dutch guideline for preventing nosocomial transmission of highly resistant microorganisms (HRMO). Infection. 2005;33(5-6):309-13.

32. Epidemic intelligence. [Internet]. Stockholm: European Centre for Disease Prevention and Control. Available from: http:// ecdc.europa.eu/en/activities/epidemicintelligence/pages/ epidemicintelligence_tools.aspx

33. Cohen Stuart J, Leverstein-Van Hall MA; Dutch Working Party on the Detection of Highly Resistant Microorganisms. Guideline for phenotypic screening and confirmation of carbapenemases in Enterobacteriaceae. Int J Antimicrob Agents. 2010;36(3):205-10. 
